\title{
The Use of Botulinum Toxin A in the Management of Trigeminal Neuralgia: a Systematic Literature Review
}

\author{
Anton Rubis ${ }^{1}$, Gintaras Juodzbalys ${ }^{1,2}$ \\ ${ }^{1}$ Department of Oral and Maxillofacial Surgery, Lithuanian University of Health Sciences, Kaunas, Lithuania. \\ ${ }^{2}$ Dental Implant Centre "Stilus Optimus”, Kaunas, Lithuania.
}

Corresponding Author:

Anton Rubis

Muliavina Boulevard 5-55, 220089, Minsk

Belarus

Phone: $+375299534838 ;+37068826169$

E-mail: antanas.rubis@gmail.com

\section{ABSTRACT}

Objectives: The purpose of this article is to systematically review the use, efficacy, differences between botulinum toxin type A doses and side effects of botulinum toxin type A therapy in patients with trigeminal neuralgia.

Material and Methods: The search for the performed reviews was done in PubMed and Cochrane library in English language from January 2010 up to February 2020. Inclusion criteria: full-text studies in English language, in which visual assessment scale (VAS) was present, in which patients with trigeminal neuralgia (TN) were participated and the comparison between botulinum toxin type A (BT-A) and saline was done.

Results: The review included 4 randomized, double-blind, placebo-controlled trials with 8 to 12 weeks follow-up to observe changes in VAS and in frequency of TN attacks, differences between dosages of BT-A in therapy and side effects. Mean VAS of BT-A group decreased by approximately $68 \%$ and of palcebo group decreased by approximately $21.6 \%$ after the therapy. Mean frequency of TN attacks in 3 studies of BT-A group decreased by $85 \%$, while in palcebo by only $15.9 \%$.

Conclusions: Botulinum toxin type A injection therapy is a safe and effective method in management of trigeminal neuralgia. No differences between dosages of botulinum toxin type A were found. Maximum efficacy was noticed between 6 weeks and 3 months after the procedure. Side effects were mostly facial asymmetry after injection, headaches, haematoma, which disappeared in one week.

Keywords: botulinum A toxin; botulinum neurotoxin A; trigeminal neuralgia; trigeminal nerve.

\author{
Accepted for publication: 29 June 2020 \\ To cite this article: \\ Rubis A, Juodzbalys G. \\ The Use of Botulinum Toxin A in the Management of Trigeminal Neuralgia: a Systematic Literature Review \\ J Oral Maxillofac Res 2020;11(2):e2 \\ URL: http://www.ejomr.org/JOMR/archives/2020/2/e2/v11n2e2.pdf \\ doi: $10.5037 /$ jomr.2020.11202
}




\section{INTRODUCTION}

Trigeminal neuralgia (TN) is one of the most painful disorders, which presents as recurrent, unilateral, brief but severe, electric-shock-like pains of rapid onset and short duration (up to 2 minutes) in the distribution of the trigeminal nerve. It may develop without apparent cause or be a result of another diagnosed disorder. In some patients, pain may radiate to another division, but it remains within the trigeminal dermatomes. The International Classification of Headache Disorders classify TN as classical, secondary and idiopathic [1]. $\mathrm{TN}$ is twice more common in women and usually in older individuals (above 50 years old). May also feature a constant aching pain between attacks in the affected area of moderate intensity. Mostly associated with neurovascular compression of the trigeminal nerve, it is possible to experience no-pain period for several months or even years, but time periods become shorter with time $[\underline{2}, \underline{3}]$.

The most frequent trigger actions showed were touching face (79\%), talking (54\%), chewing (44\%) and brushing teeth (31\%). This showed that for $97 \%$ of TN patients paroxysms were associated with triggers [4].

There is no special test to prove TN nowadays, that's why it is a long process and it is really important to diagnose individuals with a correct diagnosis because treatment differs. A diagnosis of TN is made by collecting and going through person's medical history and description. For a definite diagnosis, for proper diagnostics patient requires objective signs or tests that can show an underlying lesion or disease of the nervous system [ $\underline{5}$ ]. Brain imaging like magnetic resonance imaging (MRI) or computed tomography (CT) is highly recommended to exclude secondary causes because no clinical characteristics can exclude it [].

Other disorders that increase facial pain should be ruled out before a diagnosis of $\mathrm{TN}$ is made. There is postherpetic neuralgia (nerve pain that occurs after shingles), cluster headaches and a disorder of the temporomandibular joint (TMJ), which is pain in the jaw joint and muscles that control jaw movement. This is hard to diagnose due to the coincidence of the symptoms and the huge number of conditions that can cause facial pain [7].

Di Stefano et al. [] in key issues of pharmacological treatment of TN accented one more time that carbamazepine (CBZ) and oxcarbazepine, sodium channel blockers are the first line of treatment. In case of multiple side effects, when it is not possible to reach the higher dosage of medications listed above possible to add such drugs as baclofen and lamotrigine.

Pharmacological treatment should be one of the first steps in management of TN. Surgical options are available as well and may be used together with pharmaceuticals and as well additional therapies are possible. Some individuals reported that yoga helps a lot [7].

The main approach to patients with $\mathrm{TN}$ is to start with medications and then after careful follow-ups. If the patient does not respond to drug treatment the surgery is possible. Operative interventions such as microvascular decompression, percutaneous balloon compression, percutaneous glycerol rhizotomy, percutaneous radiofrequency rhizotomy and stereotactic radiosurgery, including gamma knife radiosurgery or cyberknife are also available [9]

As well, it is possible to mix treatment options like pharmacological after the surgery or to use together with complementary approaches.

Botulinum neurotoxin has been the most popular aesthetic procedure performed by plastic surgeons since 1999 [10]. In 2018 more than 1,801,033 procedures were performed in the USA [10]. Botulinum neurotoxin type A was approved for facial aesthetics in 2002 as the first botulinum toxin type A (BT-A) [10].

Botulinum toxin is a neurotoxic protein and a powerful tool in therapeutics, which is seen in the growing numbers of use. Botulinum toxin (BT) is produced by the Clostridium bacterium family [11].

Botulinum drugs are a complex mixtures of compounds which consist of BNT (exists in 7 different types named from $A$ to $G$ ), non-toxic proteins and excipients (stabilizers like human serum albumins, sugars included and buffers may be found as well to calibre the $\mathrm{PH}$ value). A completely novel use for BT emerged in 2010 [12] with the registration of BT drugs for the management of chronic migraine. Whether and how BT can have anti-depressive and anti-inflammatory effects is still a matter of debate [12]

Neurotoxin relaxes striated muscle by inhibiting acetylcholine's release from presynaptic nerve terminals blocking the neuromuscular junction. Although it is widely accepted that its therapeutic effects are restricted to the peripheral nervous system, its actions at distant and central sites are also presumed. These central effects may be the consequence of haematogenic spread, a retrograde neural transport of BT to the central nervous system. However, inhibition is only temporarily [1]] .

One proposed theory for BT-A relieving pain is by resolving muscle trigger points. And it has been 
reported that around $72 \%$ of patients have myofascial trigger points. From this, it is possible to conclude that BT might be useful in $70 \%$ of patients with TN [14].

In dentistry, controlled clinical trials have demonstrated the great efficiency in pathologies such as bruxism, TMJ disorders, neuropathic pain and more [11]

The hypothesis of this systematic review is that BT-A has no impact on TN patients.

The purpose of this article is to systematically review the use, length of effect and differences between botulinum toxin type A doses and side effects of botulinum toxin type A therapy in patients with $\mathrm{TN}$.

\section{MATERIAL AND METHODS Protocol and registration}

Analysis and inclusion criteria methods were specified in advance and documented in the protocol for systematic review according to PRISMA-P (Appendix 1).

\section{Focus questions}

The following focus question was framed according to the problem, intervention, comparison and outcome (PICO) process (Table 1):

"What is the efficacy and differences between botulinum toxin type A doses and side effects of botulinum toxin type A therapy in patients with trigeminal neuralgia?"

\section{Types of publication}

The review included studies on humans, published in English language.

\section{Types of studies}

The review included randomized, double-blind, placebo-controlled trials, which were published between January 2010 to February 2020.

\section{Information sources}

The information source was the MEDLINE (PubMed) and Cochrane library.

\section{Type of population}

Patients of all sex and ages who were diagnosed with $\mathrm{TN}$, without having any structural pathology (underwent MRI or CT).

Women who were not planning or planning to get pregnant.

\section{Disease definition}

$\mathrm{TN}$, also known as tic douloureux is a long-term pain condition that affects the trigeminal nerve, which is usually described as a sharp shooting pain or like "an electric shock" pain.

\section{Literature search strategy}

Wide search of online literature was done by using data bases: MEDLINE (PubMed) and Cochrane library to find studies that included placebo versus BT-A in the treatment or management of the TN.

Keywords used for the search included: ("trigeminal neuralgia") OR ("trigeminal nerve") AND ("botulinum A toxin") OR ("botulinum neurtoxin A"). The search was limited to English language. Articles published from January, $1^{\text {st }} 2010$ to February $20^{\text {th }}$, 2020 were searched.

Flow diagram of studies selection according PRISMA guidelines (Figure 1).

\section{Inclusion criteria}

All the included studies should have followed the inclusion criteria listed below:

- Studies of patients with TN.

- Studies of comparison between BT-A and saline.

- Randomized, double-blind, placebo controlled trials.

Table 1. PICO framework of the framed clinical question

\begin{tabular}{l|l}
\hline Patient, population, problem (P) & Individuals with trigeminal neuralgia \\
\hline Intervention (I) & Botulinum toxin type A \\
\hline Comparison (C) & Saline $(\mathrm{NaCl})$ as a placebo \\
\hline Outcome (O) & Presence or absence or reduction of pain \\
\hline Study design (S) & Randomized, double-blind, placebo controlled trials \\
\hline Focus questions & $\begin{array}{l}\text { What is the efficacy and differences between botulinum toxin type A doses and side effects of } \\
\text { botulinum toxin type A therapy in patients with trigeminal neuralgia? }\end{array}$ \\
\hline
\end{tabular}




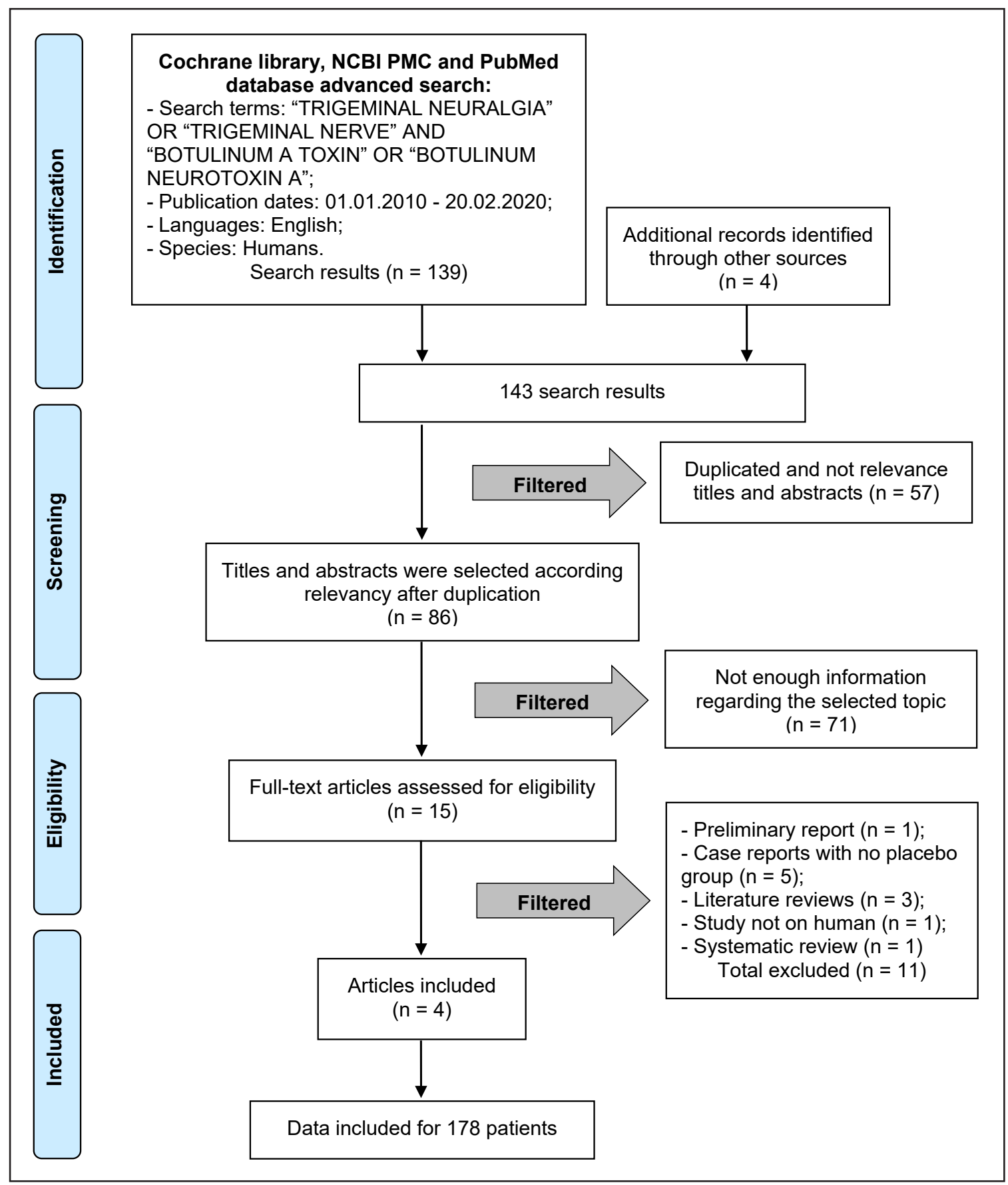

Figure 1. PRISMA flow diagram.

- Studies with the amount of more than 20 individuals.

- Studies published between Jan 2010 to Feb 2020.

- Studies in English language.

- Studies in which VAS was present.

- Studies on humans.

- Full-text article studies.

\section{Exclusion criteria}

Following exclusion criteria were applied to all review studies:

- Studies on animals, not on humans.
- Prospective study, abstracts, discussions, literature review and systematic reviews.

- Studies which include postherpetic TN.

- Studies which include neuropathic pains, with not mentioned TN.

\section{Sequential search strategy}

The selected articles were subjected to clear inclusion and exclusion criteria. Following the initial literature search, all article titles were chosen according title relevancy, considering the exclusion criteria. Following, studies were excluded based on 
irrelevant data obtained from the abstracts. The final stage of screening involved reading the full texts and confirming each study's eligibility based on the inclusion criteria and exclusion criteria.

\section{Data extraction}

The data were independently extracted from studies in the form of variables, according to the aims and themes of the present review as listed onwards.

\section{Data items}

Data were collected from the included articles and arranged in the following fields:

- "Author" - revealed the author of publication.

- "Year" - revealed the year of publication.

- "Type of study" - indicated the type of the study.

- "Groups" - indicated the type of therapy (BT-A or Placebo).

- "Sample size" - described the number of patients examined.

- "Methods" - revealed the groups type (BT-A or $0.9 \%$ saline) and sample sizes (amount of participants in each group).

- "Dosage of BT-A" - indicated the dose of BT-A used in the study.

- "Mean age"- described the average age of participants in the study or in each group.

- "Female : male ratio" - indicated the amount of males or females in the study or in each group.

- "Mean time since TN onset" - described the average time of ongoing $\mathrm{TN}$ since it was diagnosed.

- "Carbamazepine" - described the amount of participants who were on the most common medication used in treatment of $\mathrm{TN}$ before and during the studies.

- "Gabapentin" - described the amount of participants who were on the most common medication used in treatment of $\mathrm{TN}$ before and during the studies.

- "Other medications" - described the amount of participants who were on the medications, which are used in treatment of TN before and during the studies and name of medications.

- "Injection protocol" - revealed the dosages and sites of injections in patients.

- "Administration of injections" - revealed the type of injection.

- "VAS before the therapy" - described the "visual assessment scale" results before the study (before the injections).
"Frequency of TN attacks per day" - described the amount of pain attacks due to TN per day before the studies.

- "VAS at the endpoint" - described the "visual assessment scale" results after the injection course.

- "Follow-up" - indicated the amount of time during which patients were followed up.

- "Frequency of TN attacks per day at the endpoint" - described the amount of pain attacks due to TN per day after the injection course.

- "Facial asymmetry and disappearance time" described the amount of people, who had any side effect as "facial asymmetry" after injections and when it disappeared.

- "Other side effects" - described other possible side effects and amount of people who had it.

\section{Risk of bias assessment}

The Cochrane Collaboration recommends a specific tool for assessing risk of bias in each included study. Table 2 was assessed during the process of data extraction, which could influence the outcome of each selected study. The Cochrane Handbook for Systematic Reviews of Interventions was used to assess bias present in chosen studies [15].

\section{Risk of bias assessment parameters}

- Random sequence generation (-/+/?).

- Allocation concealment (-/+/?).

- Blinding of participants and personnel $(-/+/$ ? $)$.

- Blinding of outcomes assessment (-/+/?).

- Incomplete outcome data $(-/+/$ ? $)$.

- Selective reporting $(-/+/$ ? $)$.

- Other bias $(-/+/$ ? $)$.

\section{RESULTS \\ Study selection}

The review of selected publications and data extractions were performed following PRISMA flow chart guidelines. The initial identification result of articles from databases search was 143. The first exclusion was done according to the relevance: 57 duplicated titles and abstracts were excluded. After 86 records were screened of the remaining articles, 71 were excluded due to insufficient required details, articles without access, articles not presenting full-text, due to language (not in English), discussion articles. Fifteen full-text articles were assessed as eligible. Lastly, four articles met the predefined criteria and were included in the systematic review (Figure 1). 
Table. 2. Cochrane risk of bias

\begin{tabular}{l|c|c|c|c|c|c|c|c}
\hline \multicolumn{1}{c|}{ Study } & $\begin{array}{c}\text { Year of } \\
\text { publication }\end{array}$ & $\begin{array}{c}\text { Random } \\
\text { sequence } \\
\text { generation }\end{array}$ & $\begin{array}{c}\text { Allocation } \\
\text { concealment }\end{array}$ & $\begin{array}{c}\text { Binding of } \\
\text { participants } \\
\text { and personnel }\end{array}$ & $\begin{array}{c}\text { Blinding of } \\
\text { outcome as- } \\
\text { sessments }\end{array}$ & $\begin{array}{c}\text { Incomplete } \\
\text { outcome data }\end{array}$ & $\begin{array}{c}\text { Selective } \\
\text { reporting }\end{array}$ & $\begin{array}{c}\text { Other } \\
\text { bias }\end{array}$ \\
\hline Wu et al. [27] & 2012 & $?$ & $?$ & $?$ & $?$ & $?$ & - & - \\
\hline Shehata et al. [28] & 2013 & - & - & - & $?$ & - & - \\
\hline Zúñiga et al. [29] & 2013 & $?$ & + & - & $?$ & $?$ & ? \\
\hline Zhang et al. [30] & 2014 & - & - & - & $?$ & - & $?$ \\
\hline
\end{tabular}

$+=$ low risk; $?=$ unclear risk; $-=$ high risk.

\section{Exclusion of studies}

The reasons for excluding of 11 full-text articles [1626] after full-text assessment were as follows: article [16] is preliminary report, articles $[17, \underline{18}, \underline{20}, 23,24]$ are case reports with no placebo group, articles $[19,22,26]$ are literature reviews, article [21] is a study on rats, not on human and article [25] is a systematic review.

\section{Quality assessment of the included studies}

Some aspects were not presented or not presented clearly in all of the chosen articles. Mainly due to lack of information. Risk of bias is unclear for $\mathrm{Wu}$ et al. [27] in about $71.4 \%$ of assessing points. The study of Shehata et al. has [28] unclear risk of bias present in approximately $28.57 \%$. Whereas one of the lowest risk of bias was among all articles in the research of Zúñiga et al. [29], it was $57.14 \%$. One point has potentially high risk of bias in the report of Zhang et al. [30]. Also there were unclear points in $28.57 \%$, but overall it had one of the lowest risk of bias among all articles (Table 2).

\section{Study characteristics}

Overall, 4 studies were randomized, double-blind, placebo-controlled trials, from 2012 to 2014 years [27-30] (Table 3). A number of patients ranged from 20 [28] to 84 [30] (178 individuals in 4 studies) and from 10 patients [27] to 28 patients [ [30] in the groups. Groups were graded as a control placebo $(0.9 \%$ $\mathrm{NaCL}$, isotonic or $0.9 \%$ saline) and a BT-A group (1 in each of 3 studies [27-29] and 2 groups with different dosages [30]).

Placebo group has 73 individuals and BT-A has 105 individuals. Dosages of BT-A started from $25 \mathrm{U}$ [30] and up to $100 \mathrm{U}$ [28].

Mean age of patients were provided in Table 3. The study of Shehata et al. [료] shows no information to be found on mean age in test and control groups. Mean age of all participants were 45.95 (SD 10.02), in all others studies $[\underline{27}, \underline{29}, \underline{30}]$ calculated by mean age for BT-A group is 61.11 years old and for placebo group - 60.823 years old. In all study groups more females were involved than males, except in the placebo group of Wu et al. [27] half of the group were females, in placebo group of Zúñiga et al. [29], female to male ratio was $6: 10$ and in placebo group of Zhang et al. [30] males predominated by $1.85 \%$. Mean time since the TN onset is reflected in Table 3.

BT-A were administrated in injections. Saline was administrated in the same way as botulinum. Injection protocol and administration can be found below (Table 4). During the study, Wu et al. [27] $75 \mathrm{U}(1.5 \mathrm{~mL})$ of BT-A was applied at 15 points, $5 \mathrm{U}(0.1 \mathrm{~mL})$ per point, between the epidermis and dermis of the skin, where pain was detected by the patient's history. In 2013, Shehata et al. [28] BT-A was administrated in the trigger zones and each point had received 5 units of BT-A or $0.1 \mathrm{ml}$ placebo subcutaneously. In contrast, Zúñiga et al. [29], injections were always administered in a subcutaneous injection in various sites, $1 \mathrm{~cm}$ apart from one another in the path of the branch/branches involved. In the experiment by Zhang et al. [30] BT-A was administered intradermally and/or submucosally using a $1 \mathrm{~mL}$ syringe with a $0.45 \times 16 \mathrm{~mm}$ needle. BT-A or the same volume of isotonic saline was applied at 20 points, $(0.05 \mathrm{ml})$ per point, between the epidermis and dermis of the skin where pain was experienced according to the patient's description.

Wu et al. [27] avoided injection in deeper structures such as the muscles to prevent unwanted effects on the underlying muscles. Shehata et al. [28] injected posteriorly a larger dose of the toxin in the masseter to avoid undesired cosmetic effects in patients with mandibular root involvement. Patients of Zúñiga et al. [29] with involvement of the third branch of the trigeminal nerve also received intramuscularly, either $10 \mathrm{U}$ of BT or matching placebo, according to randomization in the masseter muscle, ipsilateral to the pain location. Zhang et al. [이 ] avoided injection in deeper structures such as the muscles, during the procedure to prevent unwanted effects. 
Table 3. Characteristics of included studies

\begin{tabular}{|c|c|c|c|c|c|c|c|}
\hline \multirow{4}{*}{ Study } & \multicolumn{7}{|c|}{ Characteristics } \\
\hline & \multirow{3}{*}{ Study type } & \multirow{3}{*}{\begin{tabular}{c|}
$\begin{array}{c}\text { Sample } \\
\text { size }\end{array}$ \\
$\mathrm{N}$
\end{tabular}} & \multirow{3}{*}{ Methods } & \multirow{3}{*}{$\begin{array}{c}\text { Dosage of } \\
\text { BT-A }\end{array}$} & \multirow{3}{*}{\begin{tabular}{|c|} 
Age \\
$\begin{array}{c}\text { Mean (SD), } \\
\text { years }\end{array}$
\end{tabular}} & \multirow{3}{*}{$\begin{array}{c}\text { Female/male } \\
\text { ratio }\end{array}$} & \multirow{3}{*}{\begin{tabular}{|c|} 
Time since TN onset \\
Mean (SD) \\
\end{tabular}} \\
\hline & & & & & & & \\
\hline & & & & & & & \\
\hline \multirow[b]{2}{*}{ Wu et al. [27] } & \multirow{2}{*}{$\begin{array}{l}\text { Randomized, } \\
\text { double-blind, } \\
\text { placebo-con- } \\
\text { trolled study }\end{array}$} & \multirow[b]{2}{*}{42} & $\begin{array}{l}\text { Group 1: BT-A } \\
\quad(\mathrm{n}=22)\end{array}$ & \multirow[b]{2}{*}{$75 \mathrm{U}$} & $59.14(12.58)$ & $\begin{array}{c}\text { Female: } 13 \\
(59.09 \%)\end{array}$ & 72.05 (78.48) months \\
\hline & & & $\begin{array}{c}\text { Group 2: (placebo) } \\
\text { isotonic saline }(n=20)\end{array}$ & & $58(16.91)$ & $\begin{array}{l}\text { Female: } 10 \\
\qquad(50 \%)\end{array}$ & $70(80.03)$ months \\
\hline \multirow{2}{*}{ Shehata et al. [28] } & \multirow{2}{*}{$\begin{array}{l}\text { Randomized, } \\
\text { double-blind, } \\
\text { placebo-con- } \\
\text { trolled study }\end{array}$} & \multirow{2}{*}{20} & $\begin{array}{l}\text { Group 1: BT-A } \\
\quad(\mathrm{n}=10)\end{array}$ & \multirow{2}{*}{$100 \mathrm{U}$} & \multirow{2}{*}{$\begin{array}{c}45.95(10.02) \\
\text { for all partici- } \\
\text { pants }\end{array}$} & \multirow{2}{*}{$\begin{array}{l}\text { Female: } 11 / \\
\text { male: } 9\end{array}$} & \multirow{2}{*}{$\begin{array}{l}5.33(1.52) \text { years; } \\
\text { range } 3 \text { to } 9 \text { years }\end{array}$} \\
\hline & & & $\begin{array}{l}\text { Group 2: (placebo) } \\
0.9 \% \mathrm{NaCl}(\mathrm{n}=10)\end{array}$ & & & & \\
\hline \multirow{2}{*}{ Zúñiga et al. [29] } & \multirow{2}{*}{$\begin{array}{l}\text { Randomized, } \\
\text { double-blind, } \\
\text { placebo-con- } \\
\text { trolled study }\end{array}$} & \multirow{2}{*}{36} & $\begin{array}{l}\text { Group 1: BT-A } \\
\quad(\mathrm{n}=20)\end{array}$ & \multirow{2}{*}{$50 \mathrm{U}$} & 64.5 (12.94) & $\begin{array}{c}\text { Female: } 11 / \\
\text { male: } 9\end{array}$ & $6.2(5.01)$ years \\
\hline & & & $\begin{array}{l}\text { Group 2: (placebo) } \\
0.9 \% \mathrm{NaCl}(\mathrm{n}=16)\end{array}$ & & $66.06(14.06)$ & $\begin{array}{l}\text { Female: } 6 / \\
\text { male: } 10\end{array}$ & $5.2(3.1)$ years \\
\hline \multirow{3}{*}{ Zhang et al. [30] } & \multirow{3}{*}{$\begin{array}{l}\text { Randomized, } \\
\text { double-blind, } \\
\text { placebo-con- } \\
\text { trolled study }\end{array}$} & \multirow{3}{*}{80} & $\begin{array}{c}\text { Group 1: BT-A (25 U) } \\
(\mathrm{n}=25)\end{array}$ & \multirow{3}{*}{$\begin{array}{l}25 \text { and } \\
75 \mathrm{U}\end{array}$} & $58.16(11.54)$ & Male: $40 \%$ & 91.96 (72.61) months \\
\hline & & & $\begin{array}{c}\text { Group 1: BT-A (75 U) } \\
(\mathrm{n}=28)\end{array}$ & & $62.64(13.32)$ & Male: $42.86 \%$ & 72.64 (76.45) months \\
\hline & & & $\begin{array}{l}\text { Group 2: (placebo) } \\
0.9 \% \mathrm{NaCl}(\mathrm{n}=27)\end{array}$ & & $58.41(11.74)$ & Male: $51.85 \%$ & $50.96(46.26)$ months \\
\hline
\end{tabular}

$\mathrm{N}=$ number; $\mathrm{U}=$ units per $\mathrm{ml}$ of solution; $\mathrm{BT}-\mathrm{A}=$ botulinum toxin type $\mathrm{A} ; \mathrm{TN}=$ trigeminal neuralgia.

Table 4. Injection protocol and administration

\begin{tabular}{|c|c|c|c|}
\hline \multirow[b]{2}{*}{ Study } & \multirow[b]{2}{*}{ Group } & \multicolumn{2}{|l|}{ Injection } \\
\hline & & Injection protocol & $\begin{array}{c}\text { Administration of } \\
\text { injections }\end{array}$ \\
\hline \multirow{2}{*}{ Wu et al. [27] } & BT-A & \multirow{2}{*}{$\begin{array}{c}75 \mathrm{U}(1.5 \mathrm{~mL}) \text { of BT-A were applied at } 15 \text { points, } 5 \mathrm{U}(0.1 \mathrm{~mL}) \text { per point in trigger } \\
\text { points }\end{array}$} & \multirow{2}{*}{$\begin{array}{c}\text { Intradermally and/ } \\
\text { or submucosally }\end{array}$} \\
\hline & Placebo & & \\
\hline \multirow{2}{*}{$\begin{array}{l}\text { Shehata et al. } \\
{[28]}\end{array}$} & BT-A & \multirow{2}{*}{\begin{tabular}{|} 
Every patient received either BT-A (100 U BOTOX ${ }^{\circledR}$ in $2 \mathrm{~mL}$ preservative-free normal \\
saline, resulting in a concentration of 5 units $/ 0.1 \mathrm{~mL})$ or placebo $(2 \mathrm{~mL} 0.9 \% \mathrm{NaCl})$. \\
Overall injected doses ranged from 40 units $(8$ injection points $)$ to 60 units $(12$ points $)$
\end{tabular}} & \multirow[b]{2}{*}{ Subcutaneously } \\
\hline & Placebo & & \\
\hline \multirow[b]{2}{*}{ Zúñiga et al. [29] } & BT-A & \multirow{2}{*}{$\begin{array}{l}\text { A } 1 \mathrm{~mL} \text { syringe: } 0.9 \% \text { saline plus } 50 \mathrm{U} \text { of } \mathrm{BT} \text { or only } 1 \mathrm{~mL} \text { of } 0.9 \% \text { saline were admin- } \\
\text { istered in various sites, } 1 \mathrm{~cm} \text { apart from one another in the path of the branch/branches } \\
\text { involved. }\end{array}$} & \multirow[b]{2}{*}{ Subcutaneously } \\
\hline & Placebo & & \\
\hline \multirow{3}{*}{ Zhang et al. [30] } & BT-A (25 U) & \multirow{3}{*}{$\begin{array}{l}\text { BT-A or the same volume of isotonic saline were applied at } 20 \text { points, }(0.05 \mathrm{ml}) \text { per } \\
\text { point, between the epidermis and dermis of the skin where pain was experienced ac- } \\
\text { cording to the patient's description. }\end{array}$} & \multirow{3}{*}{$\begin{array}{l}\text { Intradermally and/ } \\
\text { or submucosally }\end{array}$} \\
\hline & BT-A (75 U) & & \\
\hline & Placebo & & \\
\hline
\end{tabular}

$\mathrm{U}=$ units per $\mathrm{ml}$ of solution; $\mathrm{BT}-\mathrm{A}=$ botulinum toxin type $\mathrm{A} ; \mathrm{TN}=$ trigeminal neuralgia .

In all of the studies VAS at endpoint significantly decreased (Table 5). In 2012, Wu et al. [27] VAS of the BT-A group decreased from 7.05 (SD 2.03) to 1.8 on the last week and for placebo group from 6.88 (SD 2.25) decreased to 5 during the first week and then slowly increased. Mean attack frequency per day in the BT-A group dropped from 21.71 (SD 22.68) to 2 and in placebo group from 20.53 (SD 10.38) went to 19 attacks per day.
In the experiment, Shehata et al. [28] VAS of the BT-A group was 8.3 and then decreased to 1.8 during 12 weeks. Placebo group showed that VAS of 8.5 dropped to 8.2. Mean paroxysms frequency in the BT-A group per day dropped from 36.7 (SD 3.13) to 4 (SD 7.12) and from 39.2 (SD 3.05) went to 36.1 (SD 13.45) in placebo group. In 2013, Zúñiga et al. [29] observed VAS of 8.85 changed to 4.59 , which showed good results and mean attacks per day 
Table 5. Visual assessment scale (VAS) and frequency of TN attacks

\begin{tabular}{|c|c|c|c|c|c|c|}
\hline Study & Group & $\begin{array}{c}\text { VAS } \\
\text { before } \\
\text { therapy }\end{array}$ & $\begin{array}{c}\text { Frequency of } \\
\text { TN attacks } \\
\text { per day }\end{array}$ & $\begin{array}{c}\text { VAS } \\
\text { at endpoint }\end{array}$ & Follow-up & $\begin{array}{c}\text { Frequency of } \\
\text { TN attacks } \\
\text { at endpoint }\end{array}$ \\
\hline \multirow{2}{*}{ Wu et al. [27] } & BT-A & $7.05(2.03)$ & $21.71(22.68)$ & 1.8 & \multirow{2}{*}{$2016 \mathrm{~h} 0 \mathrm{~m} 0 \mathrm{~s}$} & 2 \\
\hline & Placebo & $(2.25)$ & $20.53(10.38)$ & 5 & & 19 \\
\hline \multirow{2}{*}{ Shehata et al. [28] } & BT-A & 8.3 & $36.7(3.13)$ & 1.8 & \multirow{2}{*}{$2016 \mathrm{~h} 0 \mathrm{~m} 0 \mathrm{~s}$} & $4(7.12)$ \\
\hline & Placebo & 8.5 & $39.2(3.05)$ & 8.2 & & $36.1(13.45)$ \\
\hline \multirow{2}{*}{ Zúñiga et al. [29] } & BT-A & 8.85 & 29.1 & 4.59 & \multirow{2}{*}{$2664 \mathrm{~h} 0 \mathrm{~m} 0 \mathrm{~s}$} & 7.1 \\
\hline & Placebo & 8.19 & 31.06 & 6.94 & & 21.25 \\
\hline \multirow{3}{*}{ Zhang et al. [30] } & BT-A (25 U) & $6.24(2.13)$ & - & 2 & \multirow{3}{*}{$1344 \mathrm{~h} 0 \mathrm{~m} 0 \mathrm{~s}$} & - \\
\hline & BT-A (75 U) & $7.18(2.21)$ & - & 1.8 & & - \\
\hline & Placebo & $6.96(1.97)$ & - & 3.8 & & - \\
\hline
\end{tabular}

$\mathrm{U}=$ units per $\mathrm{ml}$ of solution; $\mathrm{BT}-\mathrm{A}=$ botulinum toxin type $\mathrm{A} ; \mathrm{TN}=$ trigeminal neuralgia.

decreased from 29.1 to 7.1 and in placebo group VAS decreased insignificantly from 8.19 to 6.94 and mean attacks per day decreased from 31.06 to 21.25.

Zhang et al. [30] after graph evaluation noticed, that VAS of 75U BT-A decreased from 7.18 (SD 2.21) to approximately 1.8 on the $8^{\text {th }}$ week. VAS of 25 U BT-A group decreased from 6.24 (SD 2.13) to approximately 2.05 on the $8^{\text {th }}$ week and VAS of placebo group decreased from 6.96 (SD 1.97) to approximately 4.2. No significant difference was observed among patients on the $25 \mathrm{U}$ BT-A and on the 75 U BT-A. Frequency of TN attacks was not reported. Around 66.7 to $75.9 \%$ of the patients reported that their symptoms were "much improved" or "very much improved" according to the Patient Global Impression of Change [30]. Mean VAS of BT-A group before the therapy was 7.524 and after 2.398. Mean VAS of all articles [27-30] of Placebo group before the therapy was 7.63 and after 5.985. This shows us that Mean VAS of BT-A group decreased by $68 \%$ and of Placebo group by $21.6 \%$. VAS and frequency of TN attacks of BT-A groups decreased significantly compared to placebo. Mean frequency of TN attacks in studies [27-29] of BT-A group before the therapy was 29.17 and after 4.37 , in placebo group before the therapy was 30.26 and after 25.45. Mean frequency of TN attacks of BT-A group decreased by approximately $85 \%$ and in placebo by only $15.9 \%$. All data might have small mistakes due to the fact, that all articles had charts and graphs.

Main side effects were facial asymmetry, oedema, haematoma, itching and pain (Table 6). In all studies facial asymmetry were reported by 14 patients in BT-A groups, which disappeared in $6-7$ weeks and 0 cases in placebo group [27-30]. Transient oedema which disappeared in $5-7$ days was reported by 4 individuals in BT-A group and by one person from placebo group $[\underline{27}, \underline{30]}$.

Haematoma was reported by 3 patients from BT-A group and 2 by placebo patients. Itching and pain was reported by one person (2 cases) in BT-A group and by one ( 2 cases) in placebo group [ $[\underline{28}, \underline{29}]$. All reported side effects are summarized in Table 6.

Table 6. Table of side effects

\begin{tabular}{|c|c|c|c|}
\hline \multirow{3}{*}{ Study } & \multicolumn{2}{|c|}{$\begin{array}{l}\text { Facial asymmetry/ } \\
\text { disappearance } \\
\text { time }\end{array}$} & \multirow[t]{2}{*}{ Other side effects } \\
\hline & BT-A & Placebo & \\
\hline & $\mathbf{N}$ & $\mathbf{N}$ & $\mathbf{N}$ \\
\hline Wu et al. [27] & $\begin{array}{l}5 \text { patients/ } \\
\text { in } 7 \text { weeks }\end{array}$ & 0 & $\begin{array}{l}\text { Transient oedema in the area of injection was observed in } 3 \text { patients ( } 2 \text { in the BT-A group and } \\
1 \text { patient from the placebo group), facial oedema developed in } 2 \text { days and disappeared within } 7 \\
\text { days. }\end{array}$ \\
\hline \multirow{3}{*}{$\begin{array}{l}\text { Shehata et al. } \\
{[28]}\end{array}$} & \multirow{3}{*}{4 patients/- } & \multirow{3}{*}{0} & Haematoma BT-A 1 and placebo 2 \\
\hline & & & Itching BT-A 1 and placebo 1 \\
\hline & & & Pain BT-A and placebo 1 \\
\hline Zúñiga et al. [29] & 2 patients/- & 0 & Haematoma at the site of administration (2 patients in BT-A group). \\
\hline Zhang et al. [30] & $\begin{array}{l}3 \text { patients/ } \\
\text { in } 6 \text { weeks }\end{array}$ & 0 & $\begin{array}{l}\text { Transient oedema in the injection was observed in } 2 \text { patients (both from BT-A } 25 \text { U group) and } \\
\text { disappeared within } 5 \text { days. }\end{array}$ \\
\hline
\end{tabular}

$\mathrm{N}=$ number; $\mathrm{U}=$ units per $\mathrm{ml}$ of solution; $\mathrm{BT}-\mathrm{A}=$ botulinum toxin type $\mathrm{A} ; \mathrm{TN}=$ trigeminal neuralgia . 


\section{DISCUSSION}

This systematic review of the literature reported success in the use of BT-A in the management of TN. All articles were informative and showed that BT-A can have a place in the list of modern treatments and managements of TN while having less side effects than other surgical therapies such as Microvascular decompression.

In 2014, Yang et al. [31] evaluated complications after Microvascular decompression surgery, under general anaesthesia in $\mathrm{TN}$ patients. Individuals with $\mathrm{TN}$ were divided into 2 groups: the first group (G1) with 59 patients older than 65 years and another group $(\mathrm{G} 2)$ with 164 patients, younger than 64. Complications such as severe vomiting in 4 patients of the first group and in 5 from the second group. Severe headache in 1 patient (G1) and in 7 individuals (G2), facial dysesthesia in 2 patients (G1) and in 4 (G2), ataxia in 2 patients (G1) and no cases in the second group. Hearing loss in 1 patient in each group, deep venous thrombosis and pneumonia in 1 patient from the first group, meningitis in 2 individuals from the second group, 2 cases of cerebrospinal fluid leak in the second group and partial facial nerve palsy in the second group.

Higher doses of BT were found to be safe and effective and in many cases more effective than $20 \mathrm{U}$ for those patients with strong glabellar features. Many clinicians today start with dosages of 15 to $20 \mathrm{U}$ and then administer higher dosages depending on the muscle mass and/or sex of the patient [32].

However in the analysis by Zhang et al. [30] no difference between dosages of BT-A (25 U and $75 \mathrm{U}$ ) was noticed. In 2012, Wu et al. [27] BT-A dose was $75 \mathrm{U}$ and the results showed significant decrease of VAS compared to the research of Shehata et al. [28] where the dose was $100 \mathrm{U}$.

Above all, no significant differences between doses were found out because all experiments were successful. However, administration of higher dosages may provide better and longer results. Follow-up time between 8 to 12 weeks is a main review limitation.

However, Zakrzewska [3] critically pointed that review by $\mathrm{Wu}$ et al. [27] left loads of unclear details on primary outcomes, where it was not clear what kind of pain patients had and amount of it because less frequent pain attacks of higher intensity may disturb individuals more than increased amount of frequent pain attacks of lower intensity. Randomization is not described clearly as well as methods of blinding and of botulinum administration. In the work, Wu et al. [27] did not provide any details on the locations of the trigger zones and points and on the amount of injections per person, due to the fact that the size of the syringe were of $1 \mathrm{~mL}$ and the amount of injection was $1.5 \mathrm{~mL}$, that is why it is not clear, whether the refill was done or 2 syringes were used. In fact, the illustrations and texts show only injection sites of the maxillary and mandibular TN divisions, but it is also mentioned that intraoral injections were performed [33] .

According to evaluation of Risk of bias of the study by $\mathrm{Wu}$ et al. [27] an unclear risk of bias by Cochrane is shown (Table 2).

Doctors must consider the possibility of immunogenicity if low clinical responses are observed, especially if treatment was performed not for the first time. Because the neurotoxin in the different formulations it is very similar. That is why it is not recommended to change types or brands during therapies. Non-neurotoxin components can act as adjuvants that promote antibody formation and cause immune reactions that lead to treatment nonresponse and compromise outcomes. Park et al. [34] considered that, when antibodies have formed, increasing BT-A doses may be unproductive and may increase concentration of those antibodies. Additionally history of BT-A use may be important in anamnesis.

All patients had been treated with drugs to improve TN before the studies. During all studies drugs were not cancelled, but participants were instructed not to change their treatment plan during ongoing studies. CBZ was the most popular in the report by $\mathrm{Wu}$ et al. [27] and Zúñiga et al. [29]. Overall amount of individuals on CBZ in the BT-A groups was 38 and 29 in placebo group. In 2013, Shehata et al. [28] reported 11 patients on $\mathrm{CBZ}$ and 9 individuals on oxcarbazepine, but no information on allocation of patients on different medicaments was provided. In another article by Zhang et al. [30], no information on medicament treatment was found, but study mentioned that patients were on usual therapies which included CBZ, Gabapentin and opioids. Gabapentin was the second most popular medication among TN patients. Shehata et al. [28] reported that in his investigation some patients were prescribed to drink it in a combination with CBZ or even with baclofen as a triple therapy. In other studies $[\underline{27}, \underline{29}, \underline{30}]$ in Placebo group reported 12 individuals and in BT-A 8 patients. Although in $\mathrm{Wu}$ et al. [27] 3 participants were on opioids and Zhang et al. [30] mentioned opioids as a part of TN management of patients, but did not specify, which were prescribed by specialist earlier before his study. All details on medications are provided (Table 7). 
Table 7. Medication used by patients

\begin{tabular}{|c|c|c|c|c|}
\hline \multirow{3}{*}{ Study } & \multirow{3}{*}{ Group } & \multicolumn{3}{|c|}{ Medication } \\
\hline & & Carbamazepine & Gabapentin & Other medications \\
\hline & & $\mathbf{N}$ & $\mathbf{N}$ & $\mathbf{N}$ \\
\hline \multirow{3}{*}{ Wu et al. [27] } & BT-A & \multirow{2}{*}{19} & \multirow{2}{*}{7} & Opioids \\
\hline & & & & 1 \\
\hline & Placebo & 17 & 9 & 2 \\
\hline \multirow{2}{*}{ Shehata et al. [28] } & BT-A & \multirow{2}{*}{\multicolumn{3}{|c|}{$\begin{array}{l}\text { All patients had been treated with drugs known to improve TN, } 11 \text { patients were on carbamazepine } \\
\text { ( } 600 \text { to } 1400 \mathrm{mg}) \text { either alone }(\mathrm{n}=2) \text {, in combination with gabapentine }(400 \text { to } 1200 \mathrm{mg})(\mathrm{n}=5) \text { or } \\
\text { on triple therapy with baclofen }(30 \text { to } 75 \mathrm{mg})(\mathrm{n}=4) \text {. } \\
\text { Nine patients were on oxcarbazepine }(900 \text { to } 1800 \mathrm{mg}) \text { either alone }(\mathrm{n}=2) \text { or in combination with } \\
\text { gabapentine }(\mathrm{n}=5) \text {. }\end{array}$}} \\
\hline & Placebo & & & \\
\hline \multirow{3}{*}{ Zúñiga et al. [29] } & \multirow{2}{*}{ BT-A } & \multirow{2}{*}{19} & \multirow{2}{*}{1} & Amitriptyline \\
\hline & & & & 0 \\
\hline & Placebo & 12 & 3 & 2 \\
\hline \multirow{3}{*}{ Zhang et al. [30] } & BT-A (25 U) & \multirow{3}{*}{\multicolumn{3}{|c|}{$\begin{array}{l}\text { At baseline, patients usually received medications (e.g. carbamazepine, gabapentin or opioids) } \\
\text { to alleviate their pain. These medications remained unchanged during the course of the study. } \\
\text { There were no new analgesic therapies at any time during the baseline or placebo run-in period. }\end{array}$}} \\
\hline & BT-A (75 U) & & & \\
\hline & Placebo & & & \\
\hline
\end{tabular}

$\mathrm{N}=$ number; $\mathrm{U}=$ units per $\mathrm{ml}$ of solution; $\mathrm{BT}-\mathrm{A}=$ botulinum toxin type $\mathrm{A} ; \mathrm{TN}=$ trigeminal neuralgia.

Botulinum neurotoxin injections are not the first line for treatment, but it is possible to recommend this treatment as an addition to pharmaceutical or surgical treatment to relief symptoms of TN. However, it is not clear if botulinum toxin A can be used alone and how effective it will be. No information was found on comparison of BT-A therapy with surgical methods. It is possible to compare our data with the research of Leketas et al. [35], which states that surgical treatment results in a 27.53 month remission. Less efficient are pharmacotherapy, resulting in a 15.51 month remission. Surgical management significantly improve lifestyle of TN patients. Our review of maximum efficacy was noticed between 6 weeks and 3 months after the procedure, but more follow-up time is required.

Li et al. [18] evaluated $88 \mathrm{TN}$ patients which received BT-A injections with 14 months follow-up, where within 1 month in 81 patients and at 2 months in all patients $(100 \%)$ treatment was marked as "effective". Three months was the shortest period to be considered as effective and in a maximum of 46 patients was noticed full control over TN pain. The therapeutic effect decreased gradually after 3 months and the prevalence of effective treatment at 14 months was $38.6 \%$, with complete control of pain seen in 22 patients $(25 \%)$.

In 2017, Türk Börü et al. [36] in his trial with a total of 27 patients with TN, injected 100 Units of Botulinum neurotoxin A. For each root 50 Units of the solution was injected to the maxillary root, through the upper edge of the zygomatic arch and to the mandibular root, through the lower edge of the zygomatic bone to administer the solution around the trigeminal ganglion. Two roots were affected in 17 individuals and one root in 10 patients. Patients stopped their medication therapy, so only treatment with BT was administered. Treatment decreased pain score in the first week of 17 out of 28 patients $(63 \%)$, in the second month $20 / 27$ (74.1\%). In the sixth month $24 / 27$ $(88.9 \%)$ responded to treatment. At the end of sixth month 12 patients out of 27 remained pain-free. After a mean period of 54.7 (SD 30.5) (9 - 97) days, pain reverted to 15 patients. These individuals were given BT injections one more time and 7 patients out of 15 experienced pain after a mean of 87.7 (SD 20.4) (59 120) days.

Türk Börü et al. [36] used a completely different injection technique to techniques used in our articles [27-30]. Medication therapy was suppressed and follow-up period was longer.

After analysis of all articles we can expect that BT-A therapy is less effective, than the surgical treatment, but more studies are required to compare different techniques and methods.

Some systemic side effects such as dry mouth, fatigue and flu-like symptoms can occur unrelated to the spreading of the toxin from the injection site. In addition to that facial asymmetry, bleeding, ecchymosis or haematoma formation at the injection site is pretty common and can be minimized by cooling down the site of injection before and after procedure [37]. In 2013, Guardiani et al. [19] suggested to inject toxin contralateral to achieve facial symmetry, if the facial aesthetics is an anchor point to the patient. 
Anticoagulation and anti-platelet therapies are not a contraindication to BT injection and are considered safe. Some patients reported injection site pain as a side effect. The aetiology of which is not clear. There are only two absolute contraindications for BT injection: (1) a pre-existing infection at the site of injection, and (2) a pre-existing and known hypersensitivity to BT or excipients [37].

If medications are not bringing any side effects to patients, they can consider going through surgery, but $\mathrm{TN}$ will often return later. Some patients are choosing additional techniques like yoga therapy, psychiatrist courses, creative therapy, sports and other ways of managing TN pains [?].

More studies are needed to discover maximal period of pain-free time, different injection techniques and best doses of BT-A, to evaluate interactions with other medications or without possible effects on patients after surgical treatment and to create the proper treatment plan and technique.

\section{CONCLUSIONS}

Botulinum toxin type A injection therapy is a safe and effective method in management of trigeminal neuralgia. No differences between dosages of botulinum toxin type A were found. Maximum efficacy was noticed between 6 weeks and 3 months after the procedure. Side effects were mostly facial asymmetry after injection, headaches, haematoma, which disappeared in one week.

\section{ACKNOWLEDGMENTS AND DISCLOSURE STATEMENTS}

The author has not encountered any conflict of interests.

\section{REFERENCES}

1. Headache Classification Committee of the International Headache Society (IHS) The International Classification of Headache Disorders, 3rd edition. Cephalalgia. 2018 Jan;38(1):1-211. [Medline: 29368949] [doi: $10.1177 / 0333102417738202$ ]

2. National Health Services. Trigeminal neuralgia. [URL: https://www.nhs.uk]

3. Mitchell DA, Mitchell L, McCaul L. Oral medicine. Mitchell DA, Mitchell L, McCaul L, editors. Oxford Handbook of Clinical Dentistry, 6th ed. Oxford: Oxford University Press; 2014 Jul. p. 438. [doi: $10.1093 / \mathrm{med} / 9780199679850.001 .0001]$

4. Di Stefano G, Maarbjerg S, Nurmikko T, Truini A, Cruccu G. Triggering trigeminal neuralgia. Cephalalgia. 2018 May;38(6):1049-1056. [Medline: 28708009] [doi: 10.1177/0333102417721677]

5. Cruccu G, Finnerup NB, Jensen TS, Scholz J, Sindou M, Svensson P, Treede RD, Zakrzewska JM, Nurmikko T. Trigeminal neuralgia: New classification and diagnostic grading for practice and research. Neurology. $2016 \mathrm{Jul}$ 12;87(2):220-8. [Medline: 27306631] [PMC free article: 4940067] [doi: 10.1212/WNL.00000000000002840]

6. Bendtsen L, Zakrzewska JM, Abbott J, Braschinsky M, Di Stefano G, Donnet A, Cruccu G. EAN guideline on trigeminal neuralgia. European Journal of Neurology 2019;26(8):831-849. [Medline: 30860637] [doi: 10.1111/ene.13950]

7. National Institute of Neurological Disorders and Stroke (NINDS). Trigeminal Neuralgia Fact Sheet. 2013 Jun. NIH Publication No. 13-5116. [URL: https://www.ninds.nih.gov/Disorders/Patient-Caregiver-Education/Fact-Sheets/ Trigeminal-Neuralgia-Fact-Sheet]

8. Di Stefano G, Truini A. Pharmacological treatment of trigeminal neuralgia. Expert Rev Neurother. 2017 Oct; 17(10):1003-1011. [Medline: 28829200] [doi: 10.1080/14737175.2017.1370375]

9. Bick SKB, Eskandar EN. Surgical Treatment of Trigeminal Neuralgia. Neurosurg Clin N Am. 2017 Jul;28(3):429-438. [Medline: 28600016] [doi: 10.1016/j.nec.2017.02.009]

10. Cosmetic (Aesthetic) Surgery National Data Bank Statistics for 2018. The American Society for Aesthetic Plastic Surgery (ASAPS). [URL: https://surgery.org/]

11. Serrera-Figallo MA, Ruiz-de-León-Hernández G, Torres-Lagares D, Castro-Araya A, Torres-Ferrerosa O, Hernández-Pacheco E, Gutierrez-Perez JL. Use of Botulinum Toxin in Orofacial Clinical Practice. Toxins (Basel). 2020 Feb 11;12(2):112. [Medline: 32053883] [PMC free article: 7076767] [doi: 10.3390/toxins12020112]

12. Dressler D. Therapeutically relevant features of botulinum toxin drugs. Toxicon. 2020 Feb;175:64-68. [Medline: 32056697] [doi: 10.1016/j.toxicon.2019.12.005]

13. Truong D, Dressler D, Hallett M, Zachary C. Manual of Botulinum Toxin Therapy, 6th ed. Oxford: Oxford University Press; 2014;13-15. [doi: 10.1017/CBO9781139178068]

14. Gordon D, Finkelstein I, Freund B, Dhawan P. Botulinum Toxin Type-A in Pain Management. Practical Pain Management. 2013;8(8). [URL: https://www.practicalpainmanagement.com/treatments/interventional/injections/ botulinum-toxin-type-pain-management] 
15. Higgins JPT, Altman DG, Sterne JAC. Chapter 8: assessing risk of bias in included studies. In: Higgins JPT, Green S, editors. Cochrane handbook for systematic reviews of interventions version 5.1.0 (updated March 2011). The Cochrane Collaboration. 2011. [URL: http://handbook.cochrane.org/]

16. Bohluli B, Motamedi MH, Bagheri SC, Bayat M, Lassemi E, Navi F, Moharamnejad N. Use of botulinum toxin A for drug-refractory trigeminal neuralgia: preliminary report. Oral Surg Oral Med Oral Pathol Oral Radiol Endod. 2011 Jan;111(1):47-50. [Medline: 20674409] [doi: 10.1016/j.tripleo.2010.04.043]

17. Ngeow WC, Nair R. Injection of botulinum toxin type A (BOTOX) into trigger zone of trigeminal neuralgia as a means to control pain. Oral Surg Oral Med Oral Pathol Oral Radiol Endod. 2010 Mar;109(3):e47-50. [Medline: 20219585] [doi: 10.1016/j.tripleo.2009.03.021]

18. Li S, Lian YJ, Chen Y, Zhang HF, Ma YQ, He CH, Wu CJ, Xie NC, Zheng YK, Zhang Y. Therapeutic effect of Botulinum toxin-A in 88 patients with trigeminal neuralgia with 14-month follow-up. J Headache Pain. 2014 Jun 22;15(1):43. [Medline: 24952600] [PMC free article: 4077143] [doi: 10.1186/1129-2377-15-43]

19. Guardiani E, Sadoughi B, Blitzer A, Sirois D. A new treatment paradigm for trigeminal neuralgia using Botulinum toxin type A. Laryngoscope. 2014 Feb;124(2):413-7. [Medline: 23818108] [doi: 10.1002/lary.24286]

20. Xia JH, He CH, Zhang HF, Lian YJ, Chen Y, Wu CJ, Ma YQ. Botulinum toxin A in the treatment of trigeminal neuralgia. Int J Neurosci. 2016;126(4):348-53. [Medline: 26000810] [doi: 10.3109/00207454.2015.1019624]

21. Xiao L, Cheng J, Zhuang Y, Qu W, Muir J, Liang H, Zhang D. Botulinum toxin type A reduces hyperalgesia and TRPV1 expression in rats with neuropathic pain. Pain Med. 2013 Feb;14(2):276-86. [Medline: 23301515] [doi: $10.1111 / \mathrm{pme} .12017]$

22. Verma G. Role of Botulinum Toxin Type-A (BTX-A) in the Management of Trigeminal Neuralgia. Pain Res Treat. 2013;2013:831094. [Medline: 24194982] [PMC free article: 3806369] [doi: 10.1155/2013/831094]

23. Lunde HM, Torkildsen $\varnothing$, Bø L, Bertelsen AK. Botulinum Toxin as Monotherapy in Symptomatic Trigeminal Neuralgia. Headache. 2016 Jun;56(6):1035-9. [Medline: 26992044] [doi: 10.1111/head.12791]

24. Herrero Babiloni A, Kapos FP, Nixdorf DR. Intraoral administration of botulinum toxin for trigeminal neuropathic pain. Oral Surg Oral Med Oral Pathol Oral Radiol. 2016 Jun;121(6):e148-53. [Medline: 27181448] [doi: 10.1016/i.0000.2016.03.013]

25. Hu Y, Guan X, Fan L, Li M, Liao Y, Nie Z, Jin L. Therapeutic efficacy and safety of botulinum toxin type A in trigeminal neuralgia: a systematic review. J Headache Pain. 2013 Aug 21;14(1):72. [Medline: 23964790] [PMC free article: 3765392] [doi: 10.1186/1129-2377-14-72]

26. Castillo-Álvarez F, Hernando de la Bárcena I, Marzo-Sola ME. Botulinum toxin in trigeminal neuralgia. Medicina Clínica (English Edition). Med Clin (Barc). 2017 Jan;148(1):28-32. [doi: 10.1016/j.medcle.2017.01.005]

27. Wu CJ, Lian YJ, Zheng YK, Zhang HF, Chen Y, Xie NC, Wang LJ. Botulinum toxin type A for the treatment of trigeminal neuralgia: results from a randomized, double-blind, placebo-controlled trial. Cephalalgia. 2012 Apr;32(6):443-50. [Medline: 22492424] [doi: 10.1177/0333102412441721]

28. Shehata HS, El-Tamawy MS, Shalaby NM, Ramzy G. Botulinum toxin-type A: could it be an effective treatment option in intractable trigeminal neuralgia? J Headache Pain. 2013 Nov 19;14(1):92. [Medline: 24251833] [PMC free article: 4177416] [doi: 10.1186/1129-2377-14-92]

29. Zúñiga C, Piedimonte F, Díaz S, Micheli F. Acute treatment of trigeminal neuralgia with onabotulinum toxin A. Clin Neuropharmacol. 2013 Sep-Oct;36(5):146-50. [Medline: 24045604] [doi: 10.1097/WNF.0b013e31829cb60e]

30. Zhang H, Lian Y, Ma Y, Chen Y, He C, Xie N, Wu C. Two doses of botulinum toxin type A for the treatment of trigeminal neuralgia: observation of therapeutic effect from a randomized, double-blind, placebocontrolled trial. J Headache Pain. 2014 Sep 27;15(1):65. [Medline: 25263254] [PMC free article: 4194456] [doi: $10.1186 / 1129-2377-15-65]$

31. Yang DB, Wang ZM, Jiang DY, Chen HC. The efficacy and safety of microvascular decompression for idiopathic trigeminal neuralgia in patients older than 65 years. J Craniofac Surg. 2014 Jul;25(4):1393-6. [Medline: 24816027] [PMC free article: 4095006 ] [doi: $10.1097 /$ SCS.0000000000000869]

32. Nahai F, Lorenc ZP, Kenkel JM, Fagien S, Hirmand H, Nestor MS, Sclafani AP, Sykes JM, Waldorf HA. A Review of OnabotulinumtoxinA (Botox). Aesthet Surg J. 2013 Mar;33(1 Suppl):9S-12S. [Medline: 23515199] [doi: $10.1177 / 1090820 X 12474629]$

33. Zakrzewska JM. Botulinum toxin for trigeminal neuralgia--do we have the evidence? Cephalalgia. 2012 Nov; 32(15):1154-5; author reply 1156-7. [Medline: 22990690] [doi: 10.1177/0333102412459577]

34. Park JY, Sunga O, Wanitphakdeedecha R, Frevert J. Neurotoxin Impurities: A Review of Threats to Efficacy. Plast Reconstr Surg Glob Open. 2020 Jan 24;8(1):e2627. [Medline: 32095419] [PMC free article: 7015620] [doi: 10.1097/GOX.0000000000002627]

35. Leketas M, Pajèda A, Kuprys R, Gervickas A. The Characteristics of Trigeminal Neuralgia Treatment Methods. Health Sci. 2012;22(5):114-7. [doi: 10.5200/sm-hs.2012.108]

36. Türk Börü Ü, Duman A, Bölük C, Coşkun Duman S, Taşdemir M. Botulinum toxin in the treatment of trigeminal neuralgia: 6-Month follow-up. Medicine (Baltimore). 2017 Sep;96(39):e8133. [Medline: 28953646] [PMC free article: 5626289] [doi: 10.1097/MD.0000000000008133] 
37. Dashtipour K, Pedouim F. Botulinum Toxin: Preparations for Clinical Use, Immunogenicity, Side Effects, and Safety Profile. Semin Neurol. 2016 Feb;36(1):29-33. [Medline: 26866493] [doi: 10.1055/s-0035-1571213]

\section{To cite this article:}

Rubis A, Juodzbalys G.

The Use of Botulinum Toxin A in the Management of Trigeminal Neuralgia: a Systematic Literature Review

J Oral Maxillofac Res 2020;11(2):e2

URL: http://www.ejomr.org/JOMR/archives/2020/2/e2/v11n2e2.pdf

doi: $10.5037 /$ jomr.2020.11202

Copyright (c) Rubis A, Juodzbalys G. Published in the JOURNAL OF ORAL \& MAXILLOFACIAL RESEARCH (http://www.ejomr.org), 30 June 2020.

This is an open-access article, first published in the JOURNAL OF ORAL \& MAXILLOFACIAL RESEARCH, distributed under the terms of the Creative Commons Attribution-Noncommercial-No Derivative Works 3.0 Unported License, which permits unrestricted non-commercial use, distribution, and reproduction in any medium, provided the original work and is properly cited. The copyright, license information and link to the original publication on (http://www.ejomr.org) must be included. 
Appendix 1. Protocol for systematic review according to PRISMA-P

\begin{tabular}{|c|c|}
\hline Title & The Use of Botulinum Toxin A in the Management of Trigeminal Neuralgia: a Systematic Literature Review \\
\hline \multicolumn{2}{|l|}{ Introduction } \\
\hline Aim & $\begin{array}{l}\text { The purpose of this article is to systematically review the use, efficacy, differences between BT-A doses and } \\
\text { side effects of BT-A therapy in patients with TN }\end{array}$ \\
\hline Tasks & $\begin{array}{l}\text { To evaluate the efficacy and side effects of BT-A in the patients with TN. } \\
\text { To find differences between BT-A doses in the patients with TN. } \\
\text { To discover the length of effect of BT-A therapy in the patients with TN. }\end{array}$ \\
\hline \multicolumn{2}{|l|}{ Methods } \\
\hline \multirow{3}{*}{ Eligibility criteria } & $\begin{array}{l}\text { PICOS: } \\
\text { P - Patients: individuals with trigeminal neuralgia; } \\
\text { I - Intervention: Botulinum toxin A; } \\
\text { C- Comparison: saline (NaCL) as a placebo; } \\
\text { O - Outcome: presence or absence or reduction of pain; } \\
\text { S - Study design: randomized, double-blind, placebo controlled trials }\end{array}$ \\
\hline & $\begin{array}{l}\text { Inclusion criteria: } \\
\text { - Studies of patients with trigeminal neuralgia } \\
\text { - Studies of comparison between BT-A and saline } \\
\text { - Randomized, double-blind, placebo controlled trials } \\
\text { - Studies between Jan } 2010 \text { - Feb } 2020 \\
\text { - Studies with the amount of more than } 20 \text { individuals } \\
\text { - Studies in English language } \\
\text { - Studies in which VAS was present } \\
\text { - Studies on humans } \\
\text { - Full-text article studies }\end{array}$ \\
\hline & $\begin{array}{l}\text { Exclusion criteria: } \\
\text { - Studies on animals, not on humans } \\
\text { - Prospective studies, abstracts, discussions, literature reviews and systematic reviews } \\
\text { - Studies which include postherpetic trigeminal neuralgia } \\
\text { - Studies which include neuropathic pains, with not mentioned TN }\end{array}$ \\
\hline Information sources & $\begin{array}{l}\text { Electronic databases: PubMed and Cochrane library. } \\
\text { Keywords: trigeminal neuralgia, trigeminal nerve, botulinum A toxin, botulinum neurtoxin A. } \\
\text { Time period: January } 2010 \text { - February } 2020 \text {. }\end{array}$ \\
\hline Study selection & $\begin{array}{l}\text { Searching by entering the keywords in a few combinations and according to chosen inclusion criteria } \\
\text { Screening with exclusion of duplicates } \\
\text { Eligibility according to exclusion criteria } \\
\text { Including only relevant articles }\end{array}$ \\
\hline $\begin{array}{l}\text { Outcomes and } \\
\text { prioritization }\end{array}$ & $\begin{array}{l}\text { Assessing success of BT-A therapy in patients with Trigeminal neuralgia, difference in dosages and side } \\
\text { effects. }\end{array}$ \\
\hline
\end{tabular}

BT-A = botulinum toxin type $\mathrm{A} ; \mathrm{TN}=$ trigeminal neuralgia. 